\title{
Invasive Lantana camara L. Shrub in Ethiopia: Ecology, Threat, and Suggested Management Strategies
}

\author{
Firew Bekele Abebe ${ }^{1}$ \\ 1 School of Natural Resources Management and Environmental Sciences, College of Agriculture and \\ Environmental Sciences, Haramaya University, Ethiopia \\ Correspondence: Firew Bekele Abebe, School of Natural Resources Management and Environmental Sciences, \\ College of Agriculture and Environmental Sciences, Haramaya University, Ethiopia. Tel: 251-912-490-990. \\ E-mail: firewb12@gmail.com
}

Received: April 18, 2018

doi:10.5539/jas.v10n7p184

\author{
Accepted: May 18, 2018 \\ Online Published: June 15, 2018 \\ URL: https://doi.org/10.5539/jas.v10n7p184
}

\begin{abstract}
Lantana camara L. is one of the worst invasive alien species that are categorized worldwide. The objective of this review paper was to review the dispersal and threats posed by Lantana camara L. in Ethiopia and based on review results, to suggest management strategies that can bring solutions to the threats posed by the weed. Both biological characteristics of Lantana camara L. and its dispersal agents have contributed to the success of its dispersal. Even though Lantana camara L. is dispersed in other places within Ethiopia, Debrezeit, Dire Dawa, Harar and Somali are the hotspot areas for the weed. Biodiversity and potential agricultural loss, human and animal health problems and infestation in national parks are the identified threats that Lantana camara L. posed within the country. Utilization of Lantana camara L. for various purposes, prevention of its further dispersal into non-infected areas, use of fire, mechanical and biological control and awareness creation are the suggested management strategies that can bring solutions to the threats posed by the weed within the country.
\end{abstract}

Keywords: biodiversity, biological characteristics, Lantana camara, natural ecosystems

\section{Introduction}

Invasion of invasive alien species is among the most important global-scale problems experienced by natural ecosystems. Even though this biological invasion is a natural process, the recent accelerated rate of invasions is clearly anthropogenic phenomenon and constitutes one of the most important effects that humans have created on the earth (Sharma et al., 2005).

Invasive Alien Species are species which are introduced unintentionally or intentionally into a natural environment where they are not normally found, with serious negative consequences for their new environment. Such species are also termed environmental weeds (Richardson et al., 2000) and may alter ecosystem structure and function (Minchinton et al., 2006; Grice, 2006).

The unusual increase in the movement of these invasive alien species due to various reasons such as increased transport, trade, travel has accelerated their rate of introduction everywhere and these activities provide pathways for these species to cross biogeographical barriers that would usually block their way, with harmful consequences on native biological diversity (Genovesi \& Shine, 2004). Thus, as one of the greatest drivers of native biodiversity loss, invasive alien species can pose a threat to ecosystem integrity and function and therefore, to human well-being.

Like many other countries in the tropics, many invasive alien species have been introduced to Ethiopia. Among the introduced invasive alien species 35 have been so far identified (Tamiru, 2017). From the so far identified invasive alien species Parthenium hysterophorus, Prosopis juliflora, Eichhornia crassipes, Euphorbia stricta, Mimosa diplotricha, Xantium strumarium and Lantana camara L. are the foremost ones; which are a pronounced concern in Ethiopia that are posing particular problems on biodiversity, agricultural lands, rangelands, national parks, waterways, lakes, rivers, power dams, roadsides and urban green spaces with great economic and ecological consequences (Seifu et al., 2017; Tessema et al., 2009).

Lantana camara L. is a hardy evergreen perennial shrub up to $5 \mathrm{~m}$ tall, which is erect and Scandent, and native to tropical and subtropical America and the West Indies. It is a species of flowering plant within the Verbenaceae 
family. According to Demissew (2006), after its introduction in cultivation, the species had become naturalized in many parts of the tropics. It is common as an ornamental plant in all parts of the Flora of Ethiopia and is naturalized in some open disturbed areas within an altitudinal range between 500 and 2500 meter above sea level.

\subsection{Statement of the Problem}

Biological invasion is considered as the second most widespread threat to global biodiversity next to anthropogenic habitat loss and ecosystem destruction (Hulme, 2007; Adair \& Groves, 1998; Gurevitch \& Padilla, 2004). Lantana camara $\mathrm{L}$. is among the worst invasive alien species that are categorized worldwide (Zalucki et al., 2007; Lowe et al., 2000). In Ethiopia, it is also identified by the Environmental Policy and the National Biodiversity Strategy and Action Plan as a major threat to the biodiversity of the country (Tessema et al., 2009).

Lantana camara L. can become the dominant understory shrub in agricultural areas, massing out other native species and reducing biodiversity (Quentin \& Fuller, 1995). The allelochemicals which contained in different parts of the plant can interfere with seed germination and early growth (Ahmed et al., 2007) and biomass production of many plant species (Gentle \& Duggin, 1998). It may also affect native vegetation indirectly through changes in soil properties (Alemu \& Terefe, 2015). In addition to the loss of biodiversity, interference with seed germination and early growth, Lantana camara L. can reduce the effectiveness of development by choking irrigation canals, placing constraints on sustainable development, poverty alleviation, and food security within the country (Kefelegn, 2015).

Even though Lantana camara L. is a major threat it is given less attention and most of the time it is neglected in Ethiopia. The reason could be the fact that the disaster-impacts arising from this weed may often be considered not high enough to attract the attention of managers (since very little is known about the threats and dispersal of Lantana camara L. in Ethiopia) and/or impact of this invasive alien species often misunderstood (Pasiecznik et al., 2006).

According to Binggeli and Desalegn (2002), currently Lantana has spread almost all over the country, but still, it is not much perceived as a chronic environmental problem, except in few parts of Ethiopia, such as Oromia and Somali regions.

\subsection{The Purpose of the Article}

$>$ To review the dispersal and threats posed by Lantana camara L. in Ethiopia

> To review and suggest management strategies that can bring solutions to the threats posed by Lantana camara L. in Ethiopia.

\section{Dispersal}

Human-made and natural disturbances act together to help the introduction and spread of invasive alien species (Dobhal et al., 2011). Lantana camara L. spread over sixty (60) countries in the world (Day et al., 2003; Parsons \& Cuthbertson, 2001) viz, New Zealand, Mexico, Florida, Jamaica, and Brazi. It is stated in several African countries including Ethiopia (Tessema et al., 2009; Demissew, 2006), Kenya (Nanjappa et al., 2005), Uganda, Tanzania and South Africa (Kalita et al., 2012; Vardien et al., 2012).

The various colors of Lantana camara L. flowers (see Figures 1A-1C) helped it to be cultivated for its ornamental purpose (Tamiru, 2017) in Ethiopia. This process helps the plant to spread faster than other weed plants. Its utilization for fencing also contributed to its dispersal within the country.

Lantana camara L. biological attributes like high number of production of fruits each year (prolific seed production) (Mack et al., 2000) and duration of fruit production (which is throughout the year when conditions are favorable such as adequate light and moisture) (Gentle \& Duggin, 1998; Euston-Brown et al., 2007; Gujral \& Vasudevan, 1983), its ability to propagate vegetatively by a process called layering where horizontal stems take root when they are in contact with moist soil (Priyanka \& Joshi, 2013; Walton, 2006), ability of the weed seeds to germinate at any time of the year and the seed viability for longer periods ranging from 2-5 years (Wijayabandara et al., 2011), better competitive ability compared to native flora, widespread geographic range (wide ecological tolerance) (Sharma et al., 2005; Day et al., 2003) contributed to the success of its dispersal. The ability of Lantana camara L. to rapidly colonize areas of land which have been disturbed (in countries like Ethiopia where activities such as logging and clearance for agriculture are common) may allow its dispersal too (FEPPC, 2005).

In addition to its biological attributes, the quick spread of its fruit by birds (which are predominant dispersers) (Swarbrick et al., 1998) and animals that eat its fruits (Tamiru, 2017) may contributed for its dispersal; after its 
deliberate introduction into various localities in Ethiopia. Transportation of its seeds through running water within the country may also contribute to its spread (IBC, 2009).

Although Lantana camara L. can be found in areas like Adama (Abera et al., 2014), Jimma (Seifu et al., 2016), Mekelle (Badasa et al., 2013), Gamo Gofa (Bufebo et al., 2016), Bahir Dar (Assefa \& Abraha, 2014; Alemu \& Terefe, 2015), Wollega (Abera et al., 2015), Borana and Guji (Lemma et al., 2015; Bekele \& Reddy, 2015); Debre Zeit, Dire Dawa, Harar and Somali are the hot spot areas of the weed in Ethiopia (Enyew \& Raja, 2015; Demissew, 2006).

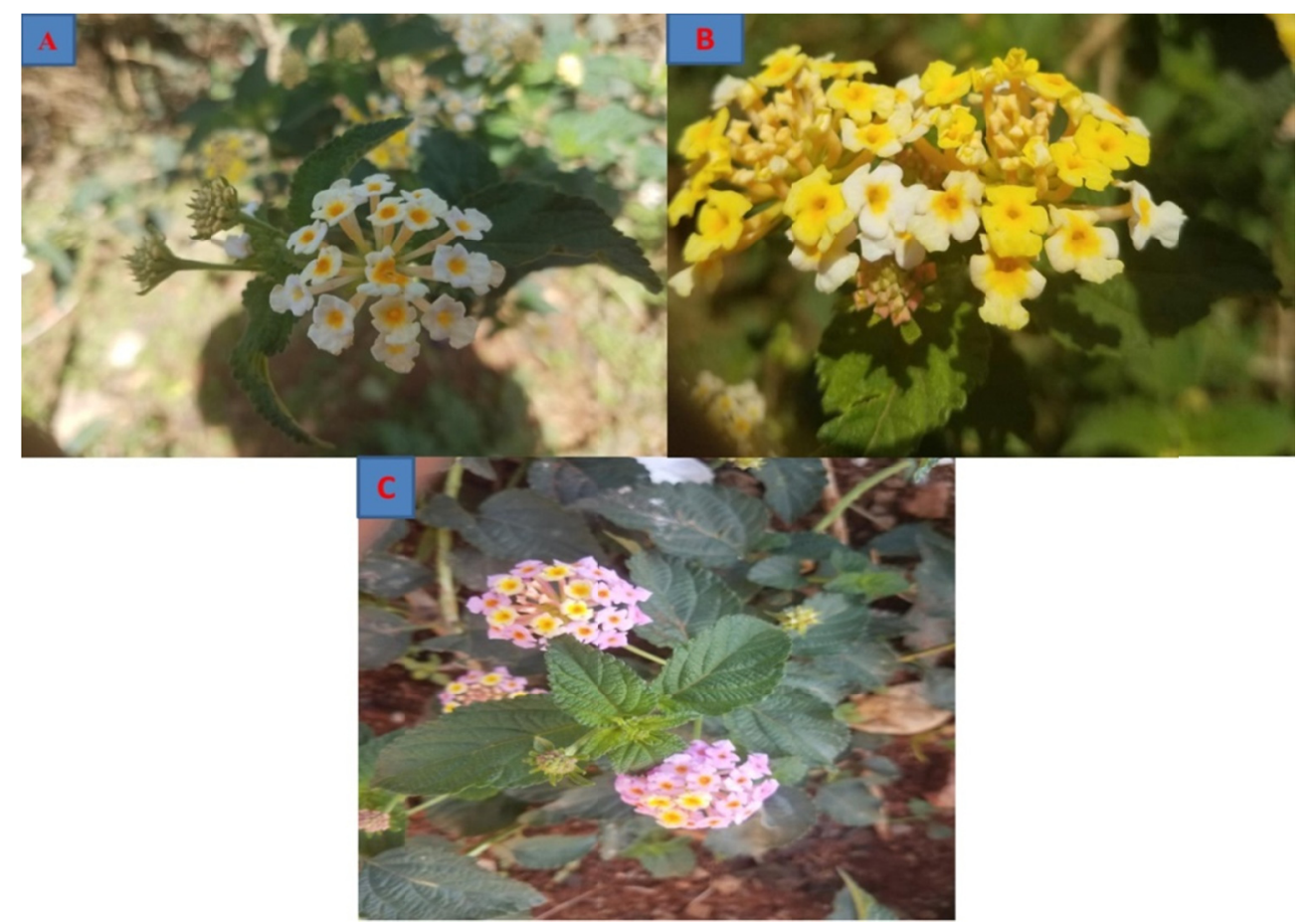

Figure 1. Various colors of flowers of Lantana camara L. in different stages (Photo by Firew Bekele and Feven Mulugeta)

\section{Threats}

\subsection{Biodiversity Loss}

Ethiopia is rich in biodiversity (UNEP, 2003). Nevertheless, there are about 35 invasive alien species including Lantana camara L. that threaten the biodiversity of the country (McGinley, 2007; Tessema et al., 2009; Anagae et al., 2004).

Lantana camara L. colonizes disturbed sites, impacting croplands, and rangelands. It generates allelochemicals by roots in the soil through root exudates (Ambika et al., 2003; Yadav et al., 2004). These allelochemicals inhibitors (like phenolic acids and alkaloids) inhibit the germination, growth, and yield of neighboring plants (Ahmed et al., 2007; Syed \& Imran, 2001) through the mechanism called non-resource mediated interference and this may adversely affect plant species diversity by displacing mature vegetation or limiting juvenile recruitment (Yurkonis et al., 2005). The other mechanism by which Lantana can affect biodiversity is through competition for resources (e.g. water, nutrients, sunlight) (Tilman, 1987). In addition to allelopathy, its fast growth and unpalatable nature (due to its unpalatability the weed experience relatively little pressure from natural predators compared to those which have evolved in their native land) favored the weed to affect biodiversity by competing out native species (Vardien et al., 2012).

In Ethiopia grasslands that are dominated by Lantana camara $\mathrm{L}$. native plant species composition and abundance were found to be reduced (Alemu \& Terefe, 2015; Belay \& Hailu, 2017; Reda \& Tewelde, 2017). Thus, under the current situation of reduction of grazing lands and presence of continued heavy grazing in the country (grazing can depress the vigor of dominant species which can compete with Lantana camara L.) the weed is capable to exclude useful forage plants and can become dominant, resulting in decreased pasture productivity, 
carrying capacity and land values (Bufebo et al., 2016). In addition to grasslands, Lantana camara L. is a serious problem affecting the biodiversity of forest areas in Ethiopia (Reda \& Tewelde, 2017). Its ability to grow in clumps in disturbed native forests (since most of the forests in Ethiopia are disturbed by human activities such as deforestation) allows it to become the dominant understory and finally leads to decline in biodiversity.

\subsection{Potential Agricultural Loss}

The adverse impacts of Lantana camara L. on agriculture have been studied in several parts of the world (Priyanka \& Joshi, 2013; Haysom \& Murphy, 2003; Ahmed et al., 2007). In Ethiopia, experimental results demonstrated the effect of Lantana camara L. on wheat (Triticum turgidum) and Maize (Zea mays) (Figures 2A and 2B), and Haricot Bean (Phaseolus vulgaris L.) (Figures 2C and 2D) on root and shoot growth and biomass when concentration increased. An experiment conducted by Tadele (2014) also showed its effect on root growth of a tef (Eragrostis tef) plant (Figure 2E). Thus, keeping Lantana camara L. on wheat, Maize, and tef (which are the dominant agricultural crops in Ethiopia) growing areas may reduce the quality and quantity of production. Lantana camara L. may have an indirect effect on crop production due to host for many insect pests that can affect human health (e.g. Malarial mosquitoes and Tse Tse flies which are vectors for African sleeping sickness) (Priyanka \& Joshi, 2013; Mack \& Smith, 2011). In addition to its effect on root and shoot growth, biomass, and host for vectors, the weed can affect mustering of cattle (by out-competing native pastures that are preferable feed for the cattle) hence affect agriculture. Lantana may also affect agriculture by providing shelter for threatening wild animals like wild cats, hyena (these animals may consume cattle, goat, and sheep), warthog (can damage crops) and others.
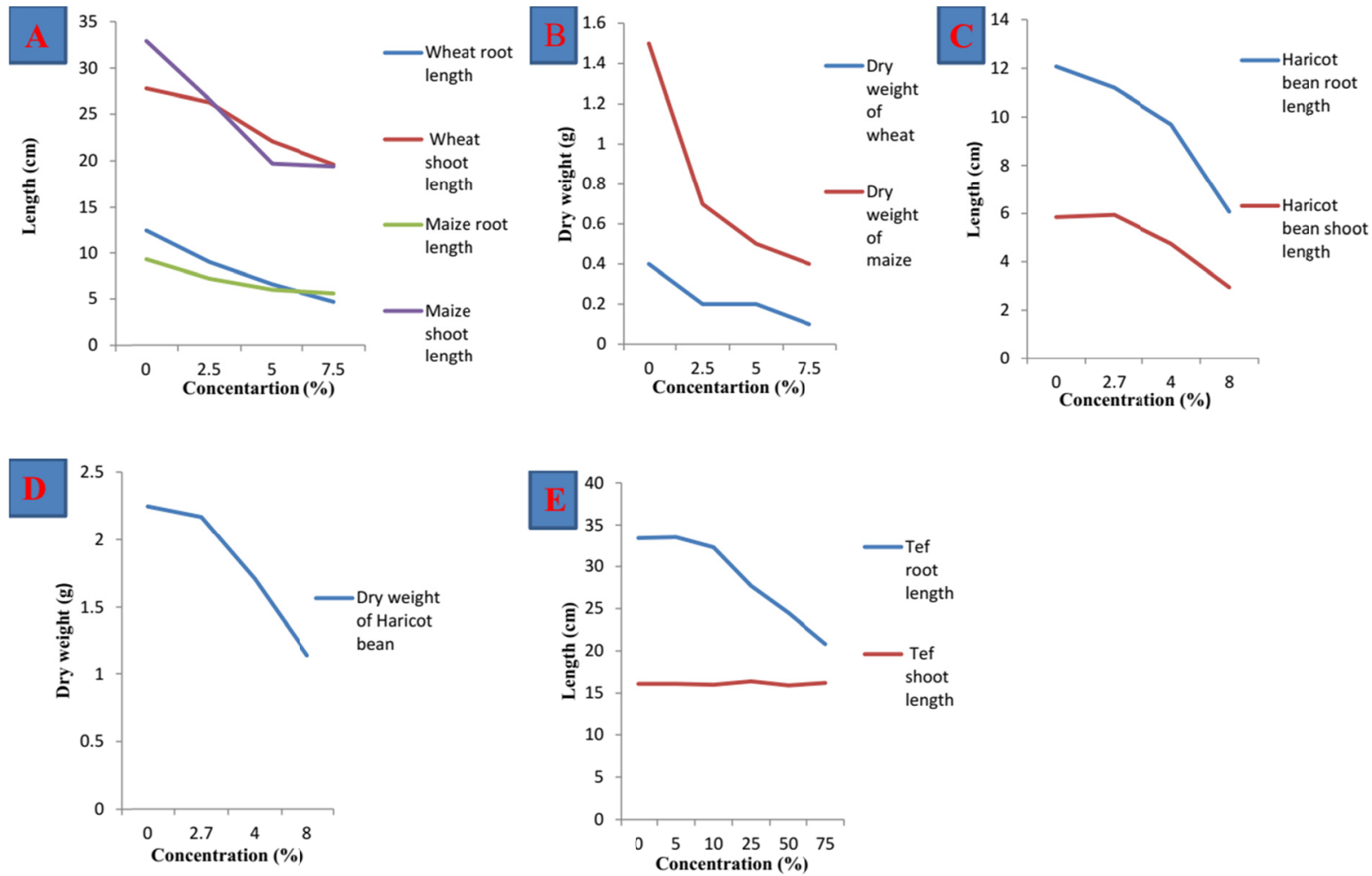

Figure 2. Effect of Lantana camara L. on root and shoot growth, and biomass (A) and (B) of wheat (Triticum turgidum Linn) and Maize (Zea mays Linn) (Enyew \& Raja, 2015), (C) and (D) of Haricot Bean (Phaseolus vulgaris L) (Degefa et al., 2016), (E) Effect of Lantana on root and shoot growth of tef (Eragrostis tef) (Tadele, 2014)

\subsection{Human and Animal Health Problems}

The nature and severity of the impacts of invasive alien species on health is a global concern (McNeely et al., 2001). Lantana camara L. is one of the potential invasive alien species that can pose a serious threat to human health (Haysom \& Murphy, 2003; Mack \& Smith, 2011). The effect of Lantana camara L. on human health can 
be direct or indirect. Feeding on the green fruit of Lantana has proved to be fatal (Sharma, 1997; Wilson, 1995; Wells \& Stirton, 1988) and this can be considered as the direct effect of Lantana camara L. on human health. However, this may not be always true because Kids and adults often consume ripe fruits of Lantana camara $\mathrm{L}$. without any ill effects in India (Priyanka \& Joshi, 2013). Also, in Ethiopia Traditional healers have been used (such as leaf and stem) Lantana camara L. to treat various ailments in humans (Table 1). These controversial research findings may come from the fact that some varieties are poisonous and some are not but it is difficult to tell which varieties are toxic so it is better to consider some forms as potentially poisonous. Indirectly Lantana camara L. can cause a health problem in humans by harboring malarial mosquitoes in bushes (Priyanka \& Joshi, 2013) and Tsetse flies (Mack \& Smith, 2011).

In Ethiopia the information on toxic plants like Lantana is scarce. However, the findings of Reda and Tewelde (2017) in Tigray region, Northern-Ethiopia and Bufebo et al. (2016) in Gamo Gofa zone indicated that Lantana camara L. is a constraint to both human and animal health. Moreover, the report of Abera et al. (2015) indicated that consumption of Lantana camara L. leaves at Wollega Zone, Western-Ethiopia result in livestock toxicosis (bloody urine). Also in Cheffa (300 km north of Addis Ababa) research results demonstrated that Lantana camara L. has affected the quality of livestock production (Tamene et al., 2000).

Table 1. Uses of Lantana camara L. by traditional healers to treat various ailments which are caused in humans in Ethiopia

\begin{tabular}{lllll}
\hline Ailments & Parts used & Application route & Area & Source \\
\hline A headache, Vomiting & Leaves & Oral & Maale and Debub Ari & Kidane et al., 2014 \\
General malaise (Mich) & Leaf & Topical (face) and Oral & Sheko, Ada'a & Giday et al., 2010; Kefalew et al., 2015 \\
Diarrhea & Steam & Oral & Abaya, Wonago & Bekele \& Reddy, 2015; Mesfin et al., 2009 \\
Fungi & Leaf & & Hararghe & Fenetahun et al., 2017 \\
\hline
\end{tabular}

\subsection{Infestation in National Parks or National Park Degradation}

Infestation in national parks can adversely affect plant (by causing a negative impact on native plant species and gradually reducing the endemic species) and wild animal biodiversity (Simba et al., 2013); and this finally may result in degradation of these protected areas and raise up management costs (McNeely, 2001).

According to Samways et al. (1996), Lantana camara L. invasion in South Africa has been related to the reduction in invertebrate diversity, tourism industry, and industrial sites. The national parks in Zimbabwe (Chatanga, 2007), Kenya (Simba et al., 2013), Australia (Fensham et al., 1994) and South Africa (Vardien et al., 2012) have been encroached by the weed. Likewise, the spread of Lantana camara L. in Ethiopia national parks currently becomes a growing concern (Alemu \& Terefe, 2015; Tessema, 2009; Hailu et al., 2004; Kassahun et al., 2004; Abdala \& Fentahun, 2017).

\section{Management Strategies}

\subsection{Utilization}

One of the possible options to manage Lantana camara L. invasion is through utilization. Lantana camara L. can be utilized for the production of biogas, compost especially vermicompost (Yadav \& Argaw, 2016) and as a green manure. Plants up to pre-bloom stage should only be used otherwise while handling such material, dispersal may take place.

Lantana camara L. can be used to control root-knot nematode (due to its nematicidal properties) (Feyisa et al., 2015), protect seed potatoes from potato tuber moth damage during storage (Sisay \& Ibrahim, 2012) and protect Tomato (Lycopersicon esculentum) (due to its antibacterial activity) from bacterial wilt caused by Ralstonia solanacearum (Alemu et al., 2013) (Table 2).

Lantana camara L. also has insecticidal properties on Musca domestica (house fly) (Cortez, 2015) and thus can be utilized as insecticidal. It can be used as a source for firewood (Tamene et al., 2000) and fuel briquette (clean energy source) (Koricho et al., 2017). It has medicinal properties too (Reddy, 2013; Begum et al., 2000; Salada et al., 2015; Kalita et al., 2012). In addition, it can be used to treat Ticks bites in livestock (Abdisa, 2017).

Currently, in India Lantana camara L. is used as a craft material for weaving baskets and making furniture (GISP, 2006). It is also used as an input for paper production. Thus, utilization of Lantana camara L. for such purpose may help in its removal and control in Ethiopia. 
Table 2. Current and proposed potential use of Lantana camara $\mathrm{L}$ in Ethiopia

\begin{tabular}{|c|c|c|c|}
\hline Use & Current use in Ethiopia & Potential use & Source \\
\hline Root-Knot nematode protection & & $x$ & Feyisa et al., 2015 \\
\hline Potato seed protection & & $\times$ & Sisay \& Ibrahim, 2012 \\
\hline Protection from bacterial wilt( for Tomato) & & $\times$ & Alemu et al., 2013 \\
\hline Insecticidal (for house fly control) & & $\times$ & Cortez, 2015 \\
\hline Biogas, vermicompost, green manure & & $\times$ & Yadav \& Argaw, 2016 \\
\hline Firewood & $\times$ & & Tamene et al., 2000 \\
\hline Medicine & $\times$ & & Reddy, 2013; Begum et al., 2000 \\
\hline Weaving baskets, making furniture and input for paper production & & $\times$ & GISP, 2006 \\
\hline
\end{tabular}

\subsection{Prevention}

Prevention of invasive alien invasive species is the most effective management strategy because it minimizes the risks (like environmental) associated with utilization of other methods (for example chemicals) and reduces management costs.

According to CBD (2009), prevention of invasive alien species includes regulating intentional introductions and minimizing unintentional introductions (through the identification of potential high-risk species and corridors) and the measures to prevent their establishment can be applied pre-border (before it leaves the source country), at the border (as it enters a country), or post-border (once it is already within a country).

Even though pre-order and at the border prevention measures cannot be applied to prevent Lantana camara L. in Ethiopia (because the weed is already established within the country), post-border measures such as Strict quarantine laws not to transport the weed from infested to the non-infested area within the country can be effective in controlling and managing the spread of the weed in to another area. People should reduce utilization of Lantana camara L. as an ornamental plant in the vicinity of their home or crop fields. This may also help prevention of Lantana camara L. further in Ethiopia. Furthermore, at a regional level, each regional government must have a biosecurity plan that covers invasive plants like Lantana camara $\mathrm{L}$. in its area (this may also help to reduce its spread into areas in which the weed is not currently found).

\subsection{Mechanical Control}

Although mechanical controls are expensive (e.g. bulldozers and tractors) and time-consuming (e.g. plowing using Oxen) and cannot be utilized in areas where Lantana camara L. is not found in isolated clumps, they can provide some relief.

The use of bulldozers and tractors (Day et al., 2003), in some cases plowing by Oxen, grubbing, the slashing of branches, and extensive digging of the root system (Love et al., 2009) are some of the mechanical measures that can be used to remove and control Lantana camara $\mathrm{L}$ in Ethiopia. Though mechanical measures, in general, may minimize disturbance to nearby vegetation and effective in killing the weed they also had their own limitation. The use of bulldozers and tractors, and plowing by Oxen may set the difficulty in removing Lantana camara L. where large areas are invaded and may result in regrowth from stumps and/or increased seedling germination from the disturbed soil. Mechanical measures can also make areas susceptible to soil erosion and other opportunistic weeds (since the measures may result in soil disturbance) unless proper care and follow up is considered. Likewise, if care is not well-thought-out grubbing, the slashing of branches and extensive digging of the root system may also result in the establishment of coppicing from slashed branches of Lantana camara $\mathrm{L}$.

\subsection{Utilization of Fire}

Regular burning will reduce the capacity of invasive alien species to survive; however, initial kill rates are variable. The effectiveness of this method will depend on the suitability of available fuel loads, litter moisture content, fire intensity, temperature, relative humidity, soil moisture and season (Bradstock \& Gill, 1993). Pasture re-establishment can then provide competition to inhibit Lantana camara L. seed germination. Although, Lantana camara L. burns readily during hot, dry conditions, even when green (Gujral \& Vasudevan 1983), moderate and low-intensity fires can promote the persistence and spread of its thickets, rather than reducing them. Furthermore, the elimination of competing native plant species (native plant species that are not fire tolerant) and increases in soil nutrients following burning (since burning can promote the release of nutrients from organic matter) can increase Lantana camara L. germination (Gentle \& Duggin 1997; Duggin \& Gentle 1998). So care should be taken when utilizing this method for Lantana camara L. control and removal. The other limitation of 
this method is that it cannot be used in non-fire tolerant vegetated areas such as rainforest, or wooded or plantation areas. But this method is favorable for savannas (since plants in savannas are fire tolerant).

\subsection{Application of Chemical}

Another expensive but effective method for management of Lantana camara L. is the utilization of Chemicals but its effectiveness depends on plant size, time of application and way of application. Numerous herbicide treatments can be used and are said to be effective by Graaff (1987) when applied as a foliar spray or to the base of the stems and cut stumps. According to Swarbrick et al. (1995), some herbicides (belonging to the phenoxy acid and benzoic acid) can be effective on Lantana camara L control and removal. Like the other management strategies utilization of chemicals requires care and follow-up.

\subsection{Biological Control}

Biological control can be considered relatively as the best and most desirable control option for the control of Lantana camara L. because it will not be influenced by constraints (because the other management options like mechanical and chemical are dependent on the land use, extent and density of the invasive populations, accessibility to invaded areas, economic value of land, and the associated costs) (Day et al., 2003). In addition, utilization of chemicals may not only be expensive and difficult but may also result in long-term environmental pollution and possible serious problems which may come upon in the future.

Several biocontrol agents (insects) have been released from time to time to manage Lantana camara L. biologically. The utilization of defoliating herbivores like Teleonemia scrupulosa Stål and Uroplata girardi Pic (since leaf defoliation can result in decreased seed production and dieback of leaves and some branches) can be used to remove and control Lantana camara L. (Day et al., 2003). In utilizing biological controls (like insects) one must make sure that natural enemies of those insects (insects which will feed upon them after the weed control or removal) are present in the area in which the method is planned to apply to them for the control of Lantana camara L. If not, utilization of biological control has also its own limitation (disadvantage).

\subsection{Awareness Creation}

Currently, issues relating to invasive woody plants like Lantana camara L. are chiefly, and sometimes only, the concern of scientists and conservationists (McNeely, 2001). This may create difficulties or limitation in eradicating and controlling the invasive plants.

Lantana camara L. can invade any area in villages, towns, and cities in the vicinity of residential and other buildings in favor of its Morphological and ecological characteristics, unlike other weeds. So society awareness, consent, and involvement are a key to control and eradicate Lantana camara L. Therefore, in order to be effective in the control of the weed in Ethiopia, mass awareness programmes should be organized by Universities, NGOs, Environmental protection authority and others for the local people to make them aware of the hazards of this noxious invasive weed. These can serve as an excellent source of knowledge about the hazards of Lantana camara L. and may help in its mechanical control (local people can involve voluntarily during its uprooting) in its early age in areas from which the local people come from. Additionally, if it is planned to save the national parks and biodiversity, reduce the potential impact on agriculture, awareness creation programs should be organized once a year throughout Ethiopia.

\section{Conclusion}

Both biological characteristics of Lantana camara L. and its dispersal agents have contributed to the success of its dispersal. Even though Lantana camara L. is dispersed in other places within Ethiopia, Debrezeit, Dire Dawa, Harar and Somali are the hotspot areas for the weed which require special attention. Biodiversity and potential agricultural loss (i.e. the effect of Lantana camara L. on few agricultural crops have been studied in Ethiopia; so further studies should be conducted to see the effect of the weed on other agricultural crops), human and animal health problems (although there are contradicting findings which require further investigation), infestation in national parks are the identified threats that Lantana camara L. posed within the country. Lantana camara L. utilization for various purposes, prevention of its further dispersal into non-infected areas, use of fire, mechanical and biological control (i.e. all require careful control and follow-up) and awareness creation are the suggested management strategies that can bring solutions to the threats posed by the weed within Ethiopia.

\section{Acknowledgements}

I would like to thank Haramaya University for covering the publication fee of this review paper. Special thanks will go to the all who contributed in manuscript preparation. 


\section{References}

Abdala, T., \& Fenetahun, Y. (2017). Review on Floristic Diversity and Threated Plant Species in Babile Elephant Sanctuary in East Hararge, Ethiopia. Environment and Sustainability, 1(1), 1-6. https://oi.org/10.11648/ j.env.20170101.11

Abdisa, T. (2017). Review on Traditional Medicinal Plant and its Extract Effect on Tick Control in Ethiopia. Journal of Veterinary Medicine and Research, 4(4), 1082.

Abera, D., Birhanu, T., \& Abda, S. (2015). Survey of Toxic Plants in Livestock at Horro Gudurru Wollega Zone, Western Ethiopia. Journal of Biology, Agriculture, and Healthcare, 5(1), 101-106.

Abera, D., Jibat, T., Sori, T., Feyisa, A., \& Beyene, T. (2014). Assessment of Plant and Chemical Poisoning In Livestock in Central Ethiopia. Journal of Environmental and Analytical Toxicology, 4(3), 1-6. https://doi.org/10.4172/2161-0525.1000215

Adair, R. J., \& Groves, R. H. (1998). Impact of Environmental Weeds on Biodiversity: A Review and Development of a Methodology. Biodiversity Group, Environment Australia, Canberra.

Ahmed, R., Uddin, M. B., Khan, M. A. S. A., \& Mukul, S. A. (2007). Allelopathic effects of Lantana camara on germination and growth behavior of some agricultural crops in Bangladesh. Journal of Forestry Research, 18(4), 301-304. https://doi.org/10.1007/s11676-007-0060-6

Alemu, D., Lemessa, F., Wakjira, M., \& Berecha, G. (2013). Antibacterial Activity of some Invasive Alen Species Extracts Against Tomato (Lycopersicon esculentum Mill.) Bacterial wilt caused by Ralstonia solanacearum (Smith). Plant Pathology Journal, 12(2), 61-70. https://doi.org/10.3923/ppj.2013.61.70

Alemu, S. C., \& Terefe, A. A. (2015). Impact of invasion: A case study on the ecological and socioeconomic impact of Lantana camara (L.) in Abay Millennium Park (AMP), Bahir Dar, Ethiopia. Journal of Ecology and the Natural Environment, 7(5), 132-145. https://doi.org/10.5897/JENE2015.0514

Ambika, S. R., Poornima, S., Palaniraj, R., Sati, S. C., \& Narwal, S. S. (2003). Allelopathic plants. 10. Lantana camara L. Allelopathy Journal, 12(2), 147-162.

Anthony, D. (2008). Queensland leads national approach to lantana eradication. Retrieved from http://www.dpi.qld.gov.au/cps/rde/dpi/hs.xsl/30_10514_ENA_HTML.htm

Assefa, T., \& Abraha, B. (2014). Assessment of Soil Seed Bank Composition in Bezawit Forest at Abay Millenium Park, Bahir Dar, Ethiopia. International Journal of Integrative Sciences, Innovation, and Technology, 3(1), 12-21.

Badasa, S., Undrala, G. S., \& Unnithan, C. R. (2013). Chemical Composition and Antibacterial Activity of Essential Oil of Lantana Camara L. of Mekelle, Ethiopia. International Journal of Pharmacy and Technology, 5(1), 5129-5135.

Begum, S., Wahab, A., \& Siddiqui, B. S. (2000). Pentacyclic triterpenoids from the aerial parts of Lantana camara. Chemical and Pharmaceutical Bulletin, 51, 134-137. https://doi.org/10.1248/cpb.51.134

Belay, T. B., \& Hailu, A. A. (2017). Assessment of the Invasive Alien Plant Species Lantana Camara in Nile River Millennium Park, Bahir Dar, Ethiopia. Global Journal of Science Frontier Research: C Biological Science, 17(1), 18-26.

Binggeli, P., \& Desalegn, D. (2002). Lantana camara: The Invasive Shrub That Threatens to Drive People out of Their Land (pp. 4-6). Wildlife and Natural History Society.

Bradstock, R. A., \& Gill, A. M. (1993). Fire in semiarid, malle shrublands-size of flames from discrete fuel arrays and their role in the spread of fire. International Journal of Wildland Fire, 3(1), 3-12. https://doi.org/10.1071/WF9930003

Bufebo, B., Tessema, T., \& Fisshaie, R. (2016). Spatial Distribution and Abundance of Invasive Alien Plant Species in Gamo Gofa Zone, Ethiopia. International Journal of Innovative Research and Development, 5(1), 23-33.

CBD. (2009). Invasive Alien Species a threat to Biodiversity. Montreal, Quebec, Canada.

Chatanga, P. (2007). Impact of the Invasive Alien Species, Lantana camara L. on Native Vegetation in Northern Gonarezhou National Park Zimbabwe (Unpublished Master's thesis, National University of Lesotho). 
Cortez, A. O. (2015). Insecticidal effects of leaves, flowers, and fruits of Lantana camara Linn. (Philippine Kantutay) on Musca domestica L. (Philippine Houseflies). Journal of Natural Product and Plant Resources, $5(5), 26-35$.

Day, M. D., Wiley, C. J., Playford, J., \& Zalucki, M. P. (2003). Lantana current management status and future prospects (Monograph 102). ACIAR, Canberra.

Degefaa, I., Shanko, D., \& Yadetab, B. (2016). Haricot Bean (Phaseolus vulgaris L) genotypes at early growth stage under the effect of allelopathic leaf extract of Lantana (Lantana Camara L.). International Journal of Current Science, 19(3), 72-80.

Demissew, S. (2006). Flora of Ethiopia and Eritrea (Vol. 5, p. 507).

Dobhal, P. K., Kohli, R. K., \& Batish, D.R. (2011). Impact of Lantana camara L. invasion on riparian vegetation of Nayar region in Garhwal Himalayas (Uttarakhand, India). Journal of Ecology and the Natural Environment, 3(1), 11-22. Retrieved from http://www.academicjournals.org/jene

Enyew, A., \& Raja, N. (2015). Allelopathic Effect of Lantana camara L. Leaf Powder on Germination and Growth Behaviour of Maize, Zea mays Linn. and Wheat, Triticum turgidum Linn. Cultivars. Asian Journal of Agricultural Science, 7(1), 4-10. https://doi.org/10.19026/ajas.7.5154

Euston-Brown, D., Rathogwa, N., \& Richardson, D. M. (2007). Protocol-based on Ecological criteria for Mesic Savannas and Sweet Grassveld for the Working for Water Programme. Report to the Working for Water Programme, Working for Water, Cape Town.

FEPPC. (Florida Exotic Pest Plant Council). (2005). Lantana camanara. Florida Exotic Pest Plant Council.

Feyisa, B., Lencho, A., Selvaraj, T., \& Getaneh, G. (2016). Evaluation of some botanicals and Trichoderma harzianum against root-knot nematode (Meloidogyne incognita (Kofoid and White) Chit wood) in tomato. Journal of Entomology and Nematology, 8(2), 11-18. https://doi.org/10.5897/JEN2015.0145

Genovesi, P., \& Shine, C. (2004). European Strategy on IAS Convention on the Conservation of European Wildlife and Habitats (Bern Convention) (pp. 1-68). Nature and Environment, Switzerland.

Gentle, C. B., \& Duggin, J. A. (1997). Allelopathy as a competitive strategy in persistent thickets of Lantana camara L. in three Australian forest communities. Plant Ecology, 132, 85-95. https://oi.org/10.1023/ A: 1009707404802

Gentle, C. B., \& Duggin, J. A. (1998). Interference of Choricarpia Leptopetala by Lantana camara with Nutrient Enrichment in Mesic Forests on the Central Coast of NSW. Plant Ecology, 136, $205-211$. https://doi.org/10.1023/A:1009784706714

GISP. (2006). Invasive species and poverty: Exploring the links. South African National Biodiversity Institute. Cape Town, South Africa.

Graaff, J. L. (1987). The seed flies Ophiomyia lantanae and other factors responsible for reducing germination in Lantana camara forms found in Natal. South African. Journal of Botany, 53, 104-107. https://doi.org/ $10.1016 / \mathrm{S} 0254-6299(16) 32625-4$

Grice, A. C. (2006). The impacts of invasive plant species on the biodiversity of Australian rangelands. The Rangeland Journal, 28, 27-35. https://doi.org/10.1071/RJ06014

Gujral, G. S., \& Vasudevan, P. (1983). Lantana camara L., a problem weed. Journal of Scientific and Industrial Research, 42, 281-286.

Gurevitch, J., \& Padilla, D. K. (2004). Are invasive species a major cause of extinctions? Trends in Ecology and Evolution., 19, 470-474. https://doi.org/10.1016/j.tree.2004.07.005

Haysom, K. A., \& Murphy, S. T. (2003). The status of invasiveness of forest tree species outside their natural habitat: a global review and discussion paper. Forest Health and Bio-security Working Paper FBS/3E.Forestry Department. FAO, Rome.

Holm, L. G., Plucknett, D. L., Pancho, J. V., \& Herberger, J. P. (1991). The World's Worst Weeds: Distribution and Biology. Krieger Publishing Company, Malabar, Florida.

Hulme, P. E. (2007). Biological invasions in Europe: Drivers, pressures, states, impacts, and responses. In R. Hester \& R. M. Harrison (Eds.), Biodiversity under Threat Issues in Environmental Science and Technology (pp. 56-80). Royal Society of Chemistry, Cambridge. https://doi.org/10.1039/9781847557650-00056

IBC. (2009). Threats to biodiversity caused by invasive species. Institute of Biodiversity Conservation, Ethiopia. 
Kalita, S., Kumar, G., Karthik, L., \& Rao, K. V. B. (2012). A Review of Medicinal Properties of Lantana camara Linn. Review Article. Research Journal of Pharmacy and Technology, 5(6), 711-715.

Kathiresan, R. M. (2004). Invasive weeds in agroecosystems of South India. National Workshop on Invasive Alien Species and Biodiversity in India (p. 149). Banaras Hindu University, Vanarasi, India.

Kefelegn, H. (2015). Invasive Alien Weed Species Impacts on Biodiversity and Socio-Economic Aspect in Ethiopia: A Review. International Journal of Science and Research, 4(10), 2179-2185.

Koricho, S. A., Leta, S., Soromessa, T., \& Khan, M. M. (2017). Fuel Briquette Potential of Lantana camara L. Weed Species and its Implications for Weed Management and Recovery of Renewable Energy Sources in Ethiopia. IOSR Journal of Environmental Science, Toxicology and Food Technology, 11(11), 41-51.

Lemma, B., Tessema, T., \& Fessehaie, R. (2015). Distribution, abundance and socio-economic impacts of invasive plant species (IPS) in Borana and Guji Zones of Oromia National Regional State, Ethiopia. Basic Research Journal of Agricultural Science and Review, 4(9), 271-279.

Love, A., Babu, S., \& Babu, C. R. (2009). Management of Lantana, an invasive alien weed, in forest ecosystems of India. Current Science, 97, 1421-1429.

Mack, R. N., \& Smith, M. C. (2011). Invasive plants as catalysts for the spread of human parasites. NeoBiota, 9 , 13-29. https://doi.org/10.3897/neobiota.9.1156

McNeeley, J. A., Mooney, H. A., Neville, L. E., Schei, P., \& Waage, J. K. ( 2001). Global Strategy on Invasive Alien Species. UCN-The World Conservation Union, Gland.

McNeely, J. A. (2001). The Great Reshuffling: Human Dimensions of Invasive Alien Species. IUCN, Gland, Switzerland and Cambridge, UK.

Minchinton, T. E., Simpson, J. C., \& Bertness, M. D. (2006). Mechanisms of exclusion of native coastal marsh plants by an invasive grass. Journal of Ecology, 94, 342-354. https://doi.org/10.1111/j.1365-2745.2006. 01099.x

Nanjappa, H. V., Saravanane, P., \& Ramachandrappa, B. K. (2005). Biology and management of Lantana camara L. A review. Agricultural Reviews, 26, 272-280.

Parsons, W. T., \& Cuthbertson, E. G. (2001). Common Lantana. Noxious Weeds of Australia (pp. 627-632). CSIRO, Melbourne.

Pasiecznik, N., Choge, S., Muthike, G., Chesang, S., Fehr, C., Bakewellstone, P., ... Harris, P. (2006). Putting knowledge on Prosopis into use in Kenya. Pioneering Advances in 2006 (p. 13). KEFRI, Nairobi, Kenya; HDRA, Coventry, UK.

Priyanka, N., \& Joshi, P. K. (2013). A review of Lantana camara studies in India. International Journal of Scientific and Research Publications, 3(10), 1-11.

Quentin, C. B. C., \& Fuller, J. L. (1995). Plant Invaders: The Threat to Natural Ecosystems. Biological Conservation, 79(2), 313-313.

Reda, A., \& Tewelde, F. (2017). Impact of Invasive Alien Plants on Biodiversity and Livelihood of Local Communities in Tigray, Ethiopia. World Applied Sciences Journal, 35(11), 2364-2378. https://doi.org/ 10.5829/idosi.wasj.2017.2364.2378

Reddy, N. M. (2013). Lantana Camara Linn. Chemical Constituents and Medicinal Properties: A Review. Scholars Academic Journal of Pharmacy, 2(6), 445-448.

Rosacia, W. Z. (2004). Lantana and Hagonoy: Poisonous weeds prominent in rangeland and grassland areas. Research Information Series on Ecosystems, 1(2). Department of the Environment and Natural Resources, Republic of the Philippines.

Salada, J. A. T., Balala, L. M., \& Vasquez, E. A. (2015). Phytochemical and Antibacterial Studies of Lantana camara L. Leaf Fraction and Essential Oil. International Journal of Scientific and Research Publications, $5(3), 1-5$.

Samways, M. J., Caldwell, P. M., \& Osborn, R. (1996). Ground-living invertebrate assemblages in native planted and invasive vegetation in South Africa. Agriculture, Ecosystems, and Environment, 59, 19-32. https://doi.org/10.1016/0167-8809(96)01047-X

Seifu, A., Seboka, N., Misganaw, M., Bekele, T., Merawi, E., Ayenew, A., \& Faris, G. (2017). Impact of Invasive Alien Plant, Xanthium Strumarium, On Species Diversity and Composition of Invaded Plant Communities 
in Borena Zone, Ethiopia. Biodiversity International Journal, 1(1), 00004. https://doi.org/10.15406/ bij.2017.01.00004

Seifu, A., Tamirat, A., Merawi, E., Birahanu, T., Mulatu, A., \& Emshaw, Y. (2016). Assessment of the Invasive Alien Plant Species Mimosa diplotricha in Shebe-Sombo, Kersa and Seka-Chekorsa Districts, Jimma Zone, Southwest Ethiopia. International Journal of Natural Resource Ecology and Management, 1(2), 20-24. https://doi.org/10.11648/j.ijnrem.20160102.12

Sharma, G. P., Raghubanshi, A. S., \& Singh, J. S. (2005). Lantana invasion: An overview. Weed Biology and Management, 5, 157-165. https://doi.org/10.1111/j.1445-6664.2005.00178.x

Simba, Y. R., Kamweya, A. M., Mwangi, P. N., \& Ochora, J. M. (2013). Impact of the invasive shrub, Lantana camara L. on soil properties in Nairobi National Park, Kenya. International Journal of Biodiversity and Conservation, 5(12), 803-809.

Sisay, A., \& Ibrahim, A. (2012). Evaluation of some potential botanicals to control potato tuber moth, (phthorimaea operculella) under storage condition at Bako, Western Ethiopia. International Journal of Phytopathology, 1(1), 14-18.

Space, J. C., \& Imada, C. T. (2004). Report to the Republic of Kiribati on Invasive Plant Species on the Islands of Tarawa, Abemama, Butaritari, and Maiana (pp. 1-105). Hawaii, USA.

Swarbrick, J. T., Willson, B. W., \& Hannan-Jones, M. A. (1995). The biology of Australian weeds 25. Lantana camara L. Plant Protection Quarterly, 10, 82-95.

Swarbrick, J. T., Willson, B. W., \& Hannan-Jones, M. A. (1998). Lantana camara L. In F. D. Panetta, R. H. Groves, \& R. C. H. Shepherd (Eds.), The Biology of Australian Weeds (pp. 119-136). R. G. and F. J. Richardson, Melbourne.

Syed, S., \& Imran, S. (2001). Lantana camara in the soil changes the fungal community structures and reduces the impact of Meloidoyne javanica on mung bean. Phytopathol. Mediterranean, 40, 245-252.

Tadele, D. (2014). Allelopathic Effects of Lantana (Lantana camara L.) Leaf Extracts on Germination and Early Growth of three Agricultural Crops in Ethiopia. Momona Ethiopian Journal of Science, 6(1), 111-119.

Tamiru, G. (2017). Invasive Alien Weed Species Distribution, Impacts on Agriculture, Challenge and Reaction in Ethiopia: A Review. Journal of Biology, Agriculture, and Healthcare, 7(7), 136-146.

Tessema, T., Ulrichs, C., \& Buettner, C. (2009). Invasive alien plant species in Ethiopia: Impact, challenges, and responses. Retrieved from http://www.unigoettingen.de/de/document/download/15aa8ee8edfc28378dbd674 032ceeb96.pdf/invasi236ve\%20alien\%20plant\%20species\%20in\%20ethiopia\%20impacts, \%20challenges\% 20and\%20responses.pdf

Tilman, D. (1987). On the meaning of competition and the mechanisms of competitive superiority. Functional Ecology, 1, 304-315. https://doi.org/10.2307/2389785

UNEP. (2003). Action Plan of the Environment Initiative of the New Partnership for Africa's Development (NEPAD). UNEP, Nairobi.

Vardien, W., Richardson, D. M., Foxcroft, L. C., Thompson, G. D., Wilson, J. R. U., \& Le Roux, J. J. (2012). Invasion dynamics of Lantana camara L. (sensu lato) in South Africa. A review. South African Journal of Botany, 81, 81-94. https://doi.org/10.1016/j.sajb.2012.06.002

Walton, C. (2006). Lantana camara (shrub). Department of Natural Resources, Queensland, Australia \& IUCN/SSC, Invasive Species Specialist Group (ISSG).

Wells, M. J., \& Stirton, C. H. (1988). Lantana camara: A poisonous declared weed. Farming in South Africa. Weeds A-27. Pretoria: Department of Agriculture and Water Supply.

Wilson, B. W. (1995). Report on short-term consultancy, Fiji 6-19 August 1995. SPC-German Biological Control Project, Brisbane.

Yadav, H., \& Argaw, A. (2016). Biodegradation of Lantana camara using different animal manures and assessing its manurial value for organic farming. South Indian Journal of Biological Sciences, 2(1), 52-60. https://doi.org/10.22205/sijbs/2016/v2/i1/100344

Yadav, K., Batish, D. R., Singh, H. P., \& Kohli, R. K. (2004). Allelopathic interference of Lantana camara L. nature and dynamics of allelochemical release. Bulletin of Environmental Science, 1, 69-72. 
Yurkonis, K. A., Meiners, S. J., \& Wachholder, B. E. (2005). Invasion impacts diversity through altered community dynamics. Journal of Ecology, 93, 1053-1061. https://doi.org/10.1111/j.1365-2745.2005. 01029.x

Zalucki, M. P., Day, M. D., \& Playford, J. (2007). Will biological control of Lantana camara ever succeed? Patterns, processes, and prospects. Biological Control, 42, 251-262. https://doi.org/10.1016/j.biocontrol. 2007.06.002

\section{Copyrights}

Copyright for this article is retained by the author(s), with first publication rights granted to the journal.

This is an open-access article distributed under the terms and conditions of the Creative Commons Attribution license (http://creativecommons.org/licenses/by/4.0/). 